\title{
DIGITAL AND CARTOGRAPHIC MODELLING OF VRSAC MOUNTAINS TOPOGRAPHIC EXPOSITIONS
}

DOI: http://dx.doi.org/10.18509/GBP.2015.02

UDC: 528.932:004.946(497.11)

\author{
Associate Prof. d-r Aleksandar Valjarević ${ }^{1}$ \\ M.Sci Bojana Jandziković \\ ${ }^{1}$ University of Kosovska Mitrovica Natural Science Faculty Department of Geography - Serbia \\ ${ }^{2}$ University of Kosovska Mitrovica Natural Science Faculty Department of Geography - Serbia
}

\begin{abstract}
The Vrsac Mountains (Romanian Munţii Vârşeţ), often referred to as the Hillock of Vrsac (Romanian Dealurile Vârşeţului), east of Vrsac and on the Romanian border. The total area covers $170 \mathrm{~km}^{2}$, with $122 \mathrm{~km}^{2}$ in the Serbian territory. 3D visualization can be referred to as a calculating method involving data storing and organisation, modelling and a 3 dimensional geographic data display. The work itself relies upon a morphological analysis and the Vrsac Mountains modelling in the GIS environment of DEM. For the sake of analysing the digital topographic model, programme Global Mapper 15 has been in use.
\end{abstract}

Key Words: digital, cartographic, expostions, Global, Mapper, QGIS 2.6

\section{INTRODUCTION}

Elements of a geographic environment are in a specific way mutually connected as particular and dynamic spatial systems of phenomena. Topography is one of the most important elements. The importance of expositions in terms of recent geo morphological processes primarily manifests itself as modifying the influences of solar radiation regarding the amplitudes of air and soil temperatures, mechanical rock dissolution, the interval of vegetation period etc [1]. A topographic area is a delevelled area of different topographic shapes. The expositions of topographic shapes, having come as a result of mutual geomorphological agent effects as well as the modifiers involved in the process of physical area dismemberment, are an element of topographic area delevelling. An exposition is a state of topographic side area whose contour direction is equal toparticular world sides. The sunny side temperature is a couple of degree higher than the one on the dark sides [2].The Vrsac Mountains are the highest elevation of Vojvodina, with Guduricki Vrh, being 641 metres high. They represent part of the old crystal-like mass, separated from the nearby terrain by fissure lines. Apart from the tectonics, erosive, abrasive and fluvial processes have played a part in forming the look of the Vrsac Mountains. The abrasive working of the former sea ,later to become a lake, caused terraces as high as 150-250 metres above sea level to be formed. With rivers and streams working their way, valleys were formed, allowing better accessabilty to the central part of the mountains. The accumulation of sand and slate particles as well as the sun-lit area of the slopes created conditions for wine growing. The Vrsac Mountains embrace the territory between Serbia, $122 \mathrm{~km}^{2}$, and Romania, $48 \mathrm{~km}^{2}$. The work will be analysing the expositions of the total $170 \mathrm{~km}^{2}$. 


\section{WORKING METHODOLOGY}

Digital cartography has made it possible for us to see the world in different eyes. A digital map may be defined as cartographic visualization in a digital format. The replacement of the old analogue data resources with the digital ones using the algorithm for calculating particular morphometric and topographic shape parameters gives way to an expedient and precise quantitive topographic parameter determination. The work has analysed a morphological feature, a topographic exposition on the grounds of the digital model formed. The satellites from which recordings can be taken form the European territory are satellites Eros A and Eros B.The stress is on the morphological analysis of the Vrsac Mountains slopes in the GIS of DEM environment. For the sake of analysing the digital topographic model, programme Global Mapper 16.1 has been used. What is carried out is the insertion ofDEM ( Digital Elevation Model), downloaded from the same software server functioning as Download Online Data [3]. With the digital elevation file data downloaded, the selected area gets cropped as a 200- metre contour line is derived. When the border line functioning as software Generate Contours is selected, the next step is measuring a particular mountain area by using the proper tools ( Feature Info Tool). In this way the limited Vrsac Mountains area has been calculated. Another step involves obtaining two important parametrers. Firstly, It is obtaining a three dimensional display of the Vrsac Mountains and secondly it is obtaining the river basin areas of the mountains. The 3D display is achieved through the Show 3D View tools. In the interior part of the tools' interface, various functions can be manipulated, for instance, Increase Water Level, where the entire $3 \mathrm{D}$ object can be set, having the object parameters measured, ranging from 0 metres of the world sea to the height desired being measured. The height can changeand be added topographic plasticity by using functions Emphasise Height and Supress Height. The entire display can be changed functioning as Change Display Properties. In this way, the parameters that will serve for design are set, concerning topography itself. This is highly important for the steps to come, especially at later stages for exposition classification, determined with the help of angles and sorted by colours.Obtaining the elevation model is achieved in the following steps: the Vrsac Mountains watersheds are derived in the way that follows [4].

The Generate Watershade tools are activated within the DEM. When the window opens, the total number of watersheds is checked as well as the major basin areas are determined expressed in metres. A layer is named inside the Description interface, and in this very example this is the Vrsac Mountains. The quantity of resolution is placed inside the window, as well as the Sream Cell Count, where the resolution itself is determined. The rest of the functions checked in the algorithm window are Keep the Current Function, Number of Streams, Number of Watersheds per Unit. Finally, function Calculating Watersheds is used inside the window, determined both collectively and individually, so that the total number of watersheds is achieved, including the area number of basin regions.

\section{EXPOSITION DERIVATION AND VRSAC MOUNTAINS FLT FIL}

On inserting the DEM, it is important that a projection active in the Vrsac Mountains territory be determined. Our projection file is expressed as the Hermans/ Hegel date of UTM8. The projection file is the closest to HGK 7 zone. On determining the projection and on cropping the area that determines the Vrsac Mountains border in a 200metre piedmont, there follow the next steps.

1 The DEM is inserted functioning as Common Elevation File 
2 Then the FLT FILE is stored in the function named FILE EXPORT ELEVATION GRID FORMAT

3 On opening the window, what is checked is EXPORT SLOPE DIRECTION VALUES INSTEAD OF ELEVATIONS

4 The file is to be inserted but then the DEM windows should be switched on.

5 Function Generate Contours is activated as the four world sides are marked,

6 On determining the eight sides of the world expositions, the lines are transferred into areas in order to be measured,

The function that follows is the right click on the Advanced Feature Creation Options line, so that the areas are obtained by using the tools called Created New Areas; Features from Selected Lines. Also, an area can be measured by using info tool.The combination of digital and analogue methods results in a comparison suitable for presenting digital data as adequately as possible. The advantage of Global Mapper 16.1 software lies in the fact of it being suitable for physically geographic element mapping, so it is considered to be a GIS of most geographic resemblance. The only drawback of the GIS tool is having comparatively weaker analytic functions, while being combined with Opensources QGIS 2.6 software.

\section{DEM PREPARATION AND INSERTION AND LAYER MAP FORMATION}

There are many ways and methods for inserting a DEM. One of the methods is drawing contour lines on a particular topographic map, where closed curves and altitudes are drawn too. When the lines are altitude- sorted, with the major contour line being 100 metres, and with the basic ones being 20 metres each, then all the heights are sorted into a specially designed layer named Modify Feature Info. The layer name is inserted as well as the feature class which is then stored. The line name is given including the basic height parameters with the height layer being the most important one, without which the DEM cannot be activated. The function where the layers are drawn is marked by algorithm Elevation. It is enough to insert the height and place the latter of the height measure unit, and it is also enough to determine the points as $\mathrm{x}, \mathrm{y}, \mathrm{z}$, for the software to recognize the height coordinate. With all the layers inserted into the basis, all the lines are derived, which now need to be transferred into areas, so that DEM heights will be derived from the lines, with the effect of achieving Digital Elevation Model. This procedure is far slower than the one to come next but better results are achieved because it is more precise. Another way for obtaining the DEM is its download from the software where permitted. One of the possibility implies download and transfer from the very software server (Global Mapper), which is to be found in the following command- Download Online Data. When the window is opened, with the command called Aster GDEM, data are downloaded inside the link capable of being expressed in various formats, includind DEM, Geo Tiff, DEM/USGS, KML, OZI, ASCH. The selected area is cropped and the coordinate determined with the projection, later to be stored in the PJR file. The other way to have the online maps downloaded is visiting theUSGS site of the Geological Institute, on which the category in question is to be found.

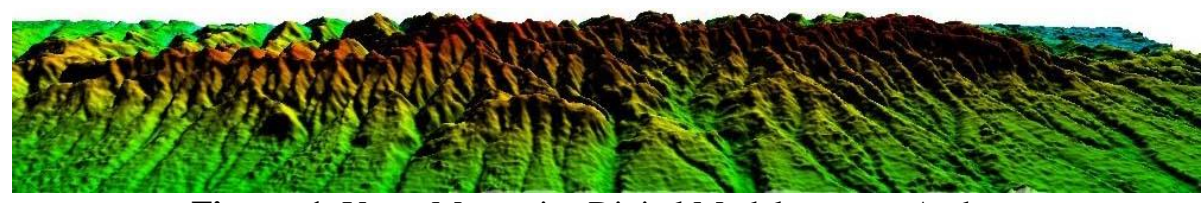

Figure 1. Vrsac Mountains Digital Model source: Authors 


\section{GEOVISUALISATION}

It is most effective to view spatial relationships among orientated areas through polar graphs as semi-proportonal [5].The steps that follow are:The basis sign- a circular outlineWhat is determined is the basis value of the guideline $(G)$, which is chosen randomly out of the numeric valuesof the mapped phenomena guidelines ( It can be the biggest, it can be the smallest or any other value) withe particular scaling of the sign chosen $(\mathrm{S})$; g- stands for the reamaining neumeric guideline values having particular scaling (s);

$\mathrm{S}$ is the basic scaling, $s=25 \mathrm{~mm}$ for the basic and numeric value of the guideline

$\mathrm{s}$ is for other scaling guideline values:

$$
(\mathrm{g}), \quad s=\sqrt{\frac{g}{T}}(\text { see formula “ } 1 ")
$$

J stands for sign semi-proportons

$$
J=c^{2} G S^{-2}=1,6817928^{2} \cdot 6,8 \cdot 25^{-2}=0.030773286008 \text { (see formula “ } 2 \text { ") }
$$

$\mathrm{T}$ - is the equalizer, an immediate equalizer for proportional mapping

$\mathrm{c}$ is the geometric figure quotient for calculating linear metrics $\mathrm{c}=1,6817928$

\begin{tabular}{|c|c|c|c|}
\hline Exposition & ${\text { Area } \mathrm{KM}^{2}}^{2}$ & $\%$ & Color \\
\hline North & 8,6 & 5.05 & \\
\hline North-East & 6,8 & 4 & \\
\hline East & 12,1 & 7.12 & \\
\hline South-East & 9,8 & 5.77 & \\
\hline South & 11.1 & 6.53 & \\
\hline South-West & 45.1 & 26.53 & \\
\hline West & 49.2 & 28.95 & \\
\hline North-West & 27.3 & 16.05 & \\
\hline Total & 170 & 100.000 & \\
\hline
\end{tabular}

Table 1. Exposition on the Vrsacke Mountain in percent and area. Source: authors

The other way to present expositions and areas is included polar graph, constructed with help of determined semi-ratio.

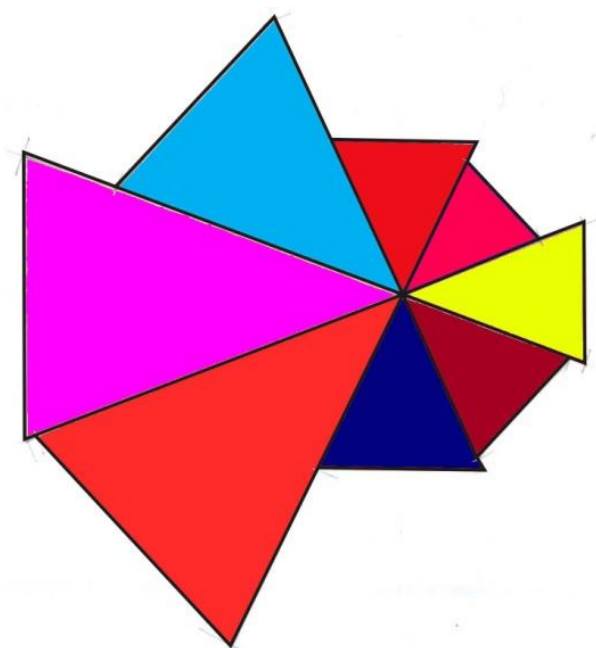

Figure 2. Polar graph of relief exposition on Vrsac mountain Source: authors 


\section{CONCLUSION}

Digital cartography has made it possible for us to see the world in different eyes. A digital map may be defined as cartographic visualization presented in a digital format $[6,7]$. The replacement of the classic analogue data with the digital ones using the algorithm for calculating particular morphometric parameters of topographic shapes has led to an efficient and precise determination of quantitive topographic parameters. The data obtained in the Vrsac Mountains example show that the largest areas are of $170 \mathrm{~km}^{2}$ sides. This implies high possibilties of wine growing and fruit plantation. The world has an increased demand for good quality wines. The basis for such wines is in good-quality grapes which grows under certain physically geographic conditions. The Vrsac Mountains meet all the demands for high quality vineyards beacause what dominates is terrains with west expositions that preserve a lot of sunshine and increased sugar contents as a result.

\section{ACKNOWLEDGMENT}

This work was financially supported by the Serbian Ministry of Education and Science project III 44006 .

\section{REFERENCES:}

[1] Пахерник, М., (2007), Дигитална анализа падина отока Раба, Геоадриа 12/1, Задар, стр.3-22.

[2] Сретеновић, Љ., (1971), Картографски метод проучавања експозичија површине рељефа за потребе просторног планрања, Зборник радова ПМФ, Географски завод, XVIII свеска, Београд, стр.105-118.

[3] Software Global Mapper 16.1.

[4] Open source software QGIS 2.6.

[5] Сретеновић, Љ., (1981), Унификација семиоразмерног тематског картирања, Зборник радова Географског института ПМФ, св.XXVIII, Београд, стр 63-79.

[6] Chang, K.T., (1982), Multi-Component Quantitative Mapping, ,,The Cartographic Journal 19" pp . 95-103.

[7] Hopkins, L.D., (1977), Methods of Generating Land Suitability Maps: „A Comparative Evaluation" Journals of American Institute of Planers 43. pp. 386-398. 
International Scientific Conference GEOBALCANICA 2015 